\title{
Children's Use of Knowledge of Place in Understanding Social Relations
}

Anne Harju

Department of Children, Youth and Society, Faculty of Education, Malmö University, Malmö, Sweden

The article explores how children use different types of knowledge of place to make sense of their relations to other children. The participants are children aged 11-12 in a small town in southern Sweden. The methodology used is place mapping with group interviews. A significant outcome is that the children connect emplaced and spatial knowledge in their efforts to understand themselves and others. Their emplaced knowledge is thus not separated from the spatial knowledge. Another significant result is that the participating children are engaged in an exchange of knowledge of place with other children and with adults. (C) 2011 The Author(s). Children \& Society (C) 2011 National Children's Bureau and Blackwell Publishing Limited.

Keywords: childhood, children's culture.

\section{Introduction}

This article explores children's understanding of social relations through their knowledge of place. The point of departure is childhood geography, in which the focus is on the construction of childhood through different spaces, places and spatial discourses (Christensen and O'Brien, 2003; Halldén, 2007; Holloway and Valentine, 2000a; McKendrick, 2000; Philo, 2000). In the field, which consists of a range of research areas, one topic is children's use and sense-making of places such as playgrounds, streets, neighbourhoods, villages and cities (Christensen and O'Brien, 2003; McKendrick, 2000). Previous studies show that children use different types of knowledge for making sense of places. Christensen (2003), for example, found that children in her study used both emplaced and spatial knowledge in their understanding of neighbourhoods. The children were emplaced by having detailed local knowledge, built up through concrete engagement. They also had spatial knowledge in relation to their locality, especially the kind that is seen as a part of the social and cultural capital that a person needs, and that adults often equip children with. Studies also show that children use emplaced and spatial knowledge of place to understand social relations. Swedish studies reveal that children, in trying to understand themselves and their relation to others, use knowledge that originates from their own experiences, but also neighbourhood discourses (Gustafson, 2006; Lieberg, 1992; Rasmusson, 1998; Van der Burght, 2006). In a study by Van der Burght (2006), for example, children had lively discussions about one neighbourhood, its inhabitants and the pupils in the school there. It was a neighbourhood that was heavily stigmatised. Collective narratives and the media played a key role for the children's understanding of the neighbourhood. These studies show that children's biographies as well as childhoods are intertwined with place: how you see yourself and others is influenced by both emplaced and spatial knowledge of place. To investigate children's use of knowledge of place is then, as Christensen (2003) points out, an exploration of the relationship between children's 
biography, identity and relations to others. The aim of this article is to investigate this connection, more specifically, how children use emplaced and spatial knowledge of place to understand themselves and other children. The starting point is a small town in the south of Sweden. It is a town that has been transformed by major economic and social changes which have created a heterogeneous and complex social situation, with different narratives flourishing about both social categories and places. It is in this context the children's use of knowledge of place is explored.

The concept of emplaced and spatial knowledge is central in the article. The notion of emplacement is referred to by Christensen (2003: 27) as the process through which consciousness, the body, sensuous presence and place are simultaneously produced and knitted together'. From this point of view, the understanding of oneself and others is created through detailed knowledge of locality, built up through concrete engagement with it and through mobility in and around it. Emplaced knowledge is thus full of personal and collective meaning. Children's movements also bring them into relationship with places that already are filled with social meaning, places that are associated with spatial knowledge, i.e. a more formalised abstract and generalised knowledge, which influences children's understanding of locality (Christensen, 2003). One such spatial knowledge is place-images. As Shields (1991) points out, sites, regardless of their character in reality, become symbols associated with particular values, historical events and feelings. Place-images are thus a set of core images that form a widely disseminated and commonly held set of images of place, which result from stereotyping or from prejudice against places or their inhabitants (Shields, 1991).

Children's making sense of places is thus a result of both the movement in and around places and the images of them, which in turn are worked on and produced in collective activity with other children and with adults.

\section{Research context}

The research was conducted in a small town in the south of Sweden, with approximately 33000 inhabitants. During the last few decades the town has been transformed by major economic and social changes. From being a town with a manufacturing industry and a shipyard playing a vital role for the local and national economy, it has steadily lost its position, with an overall decline in the local economy and unemployment as a consequence. Since the end of the 1980s the town has experienced new population gains by receiving refugees (Scarpa, 2011). The social transformation has been swift and thorough and has created a heterogeneous and complex social situation. In relation to this change, different collective narratives flourish, both about and in the town. One such narrative is that there is a great risk of being a victim of crime, such as robbery and assault. The conception of crime is linked to specific neighbourhoods, which can be likened to what Waquant (2007) calls territorially stigmatised, i.e. described as dilapidated and dangerous, and composed of a population of essentially poor people and immigrants. In relation to the social changes there are dominant narratives about different social categories. The main narrative concerns the relationship between the categories 'Swedes' and 'immigrants'. ${ }^{1}$ This is a narrative based on assumptions of difference and separation, where the 'immigrants' are seen as 'the others' and accused of being the cause of the social problems in the town (Harju, 2011; Johansson, 2011). 


\section{The context of the study}

The data presented are from a large-scale interdisciplinary research project which has aimed at exploring the drastic social and economic changes of the town from a variety of angles (Salonen, 2011). This article includes data relating to a smaller study which was carried out with young people aged 11-12 (fifth grade). This age group was chosen as it is an age when children's independent spatial distance starts to increase significantly (Elsley, 2004). At this age children are also expected to be able to read and use maps to orientate themselves in a wider environment than their neighbourhood (Berglund and Nordin, 2005; Travlou and others, 2008).

The school was identified as the research setting because of the possibility to reach representative groups of children in terms of different socioeconomic and ethnic ${ }^{2}$ backgrounds. Children were accessed through four schools, three of them located in the town centre and one on the outskirts of the town. Two of the schools are located in highly segregated areas in relation to ethnicity and socioeconomic position, and two are more mixed in relation to these aspects. Of the segregated schools, one is located in an ethnically diverse and economically disadvantaged neighbourhood with a high degree of rented accommodation. The neighbourhood, which is located in the centre of the town, has low employment rates, high social assistance recipiency rates and is considered as what Waquant (2007) calls territorially stigmatised. The other segregated school is located in a homogeneous, white ('Swedish') and affluent area on the outskirts of the town, approximately $10 \mathrm{~min}$ away by bicycle. The residential area consists mostly of owner-occupied houses and condominiums. The other two schools are located in the centre of the town and are more mixed in relation to ethnicity and socioeconomic position. The children come from different parts of the town centre, and from mixed accommodation: owner-occupied houses, condominiums and rented apartments. The three schools in the town are geographically located near each other.

\section{Data collection}

The research was carried out in September 2008, December 2008 and January 2009. A total of 114 children from ten out of ten classes participated in the study. The participation rate was 61 per cent of the total number of pupils (57\% girls and 43\% boys). The methodology used was place mapping with group interviews. The use of maps was inspired by other studies where maps have been employed to investigate children's understanding of and relation to place (Berglund and Nordin, 2005; Elsley, 2004; Travlou and others, 2008; Van der Burght, 2006). In groups of 3-4, the children were asked to place dots on a map of the town: white dots for places they like and red for those they avoid and dislike. All the children in one and the same class worked with the same map. As they were placing dots they were asked questions about what they do at the marked places, with whom, and why they like or dislike them. Each group session lasted 20-35 min. The groups mostly consisted of mixed sexes and every dot was therefore marked with the sex of the person who placed it. The well-documented influence of the school context on the research process (Castonguay and Jutras, 2009; Travlou and others, 2008) was taken into consideration, e.g. by taking the children out of the classroom to another nearby room, and by not involving teachers in the actual implementation of the research.

The dots from each class were entered in a digital map, MapArc. Different symbols were used for boys and girls. No significant difference could be recognised between the sexes, which is 
in accordance with other studies (Castonguay and Jutras, 2009; Matthews, 2003, Rasmusson, 1998). The maps from each class were then laid on top of each other to get the specific patterns for each school. The total marks of each school were given different sizes. In that way clustering of dots at specific places was identified. The interviews were recorded and transcribed. The most central places to the children in each class were identified. To ensure reliability, the verbal responses were compared with the clustering of dots. Then all places were divided into positive (favourite places) and negative (disliked/avoided), and questions such as what places are concerned and why were asked about the material.

\section{Reflections on method}

As Travlou and others (2008) point out, the method used provides a clear structure, and gets the focused attention of the participants, in relation both to the discussions and to the placing of dots. The interaction between the map, the participants and the researcher also gives new insight about opinions and criteria for choosing places. However, there are limitations with this kind of interactive approach. One concerns participation. There is a risk that a few individuals dominate the discussions and the places that are marked (Travlou and others, 2008). It was therefore important to ensure that all participants felt comfortable in offering their view of why they placed the dots as they did. Another limitation is the fact that children in one and the same class made their markings on the same map. This may have affected how the children who came after the first group placed their dots. However, many children already knew where they wanted to place their dots. This became clear when they asked for places at the beginning of the sessions. The fact that the maps did not include all the places that the participants wanted to discuss is a third limitation. The dots for these locations were placed along the edge of the map in the general location of the place. Some children also had problems finding their way on the map. This meant that they had to be given brief guidance about the geographic areas represented in the map. With the limitations being reflected upon, the overall experience of the method is that it constructs in a favourable way the dynamic relationship between children, and between children and their physical context.

\section{Children's engagement with place}

Christensen and O'Brien (2003) argue that all human beings are 'emplaced', i.e. under the influence of place. This also applies to children, whose understanding of the world is formed through experiences, memories and use of places such as the house, the street, the neighbourhood, the village and the city (Christensen, 2003). Children thus have emplaced knowledge of their locality, which also applies to the children in this study. When talking about favourite and disliked places, it becomes clear that their knowledge of these places is partly built up through mobility and concrete engagement. Just like other studies (Castonguay and Jutras, 2009; Chawla and Malone, 2003; Christensen, 2003; Lieberg, 1992; 0'Brien, 2003; Rasmusson, 1998; Travlou and others, 2008), this study shows that the participating children have emplaced knowledge that is both individual and collective - individual in a sense that they have personal experiences of the places they mark, and collective because the sense-making is done with other children. Their collective experience applies both to the research context, where the children together are engaged in making sense of places on the map, and to their concrete use of these places for identity work and getting together. An example is the McDonald's hamburger chain. Apart from the fact that the food is considered good, it functions 


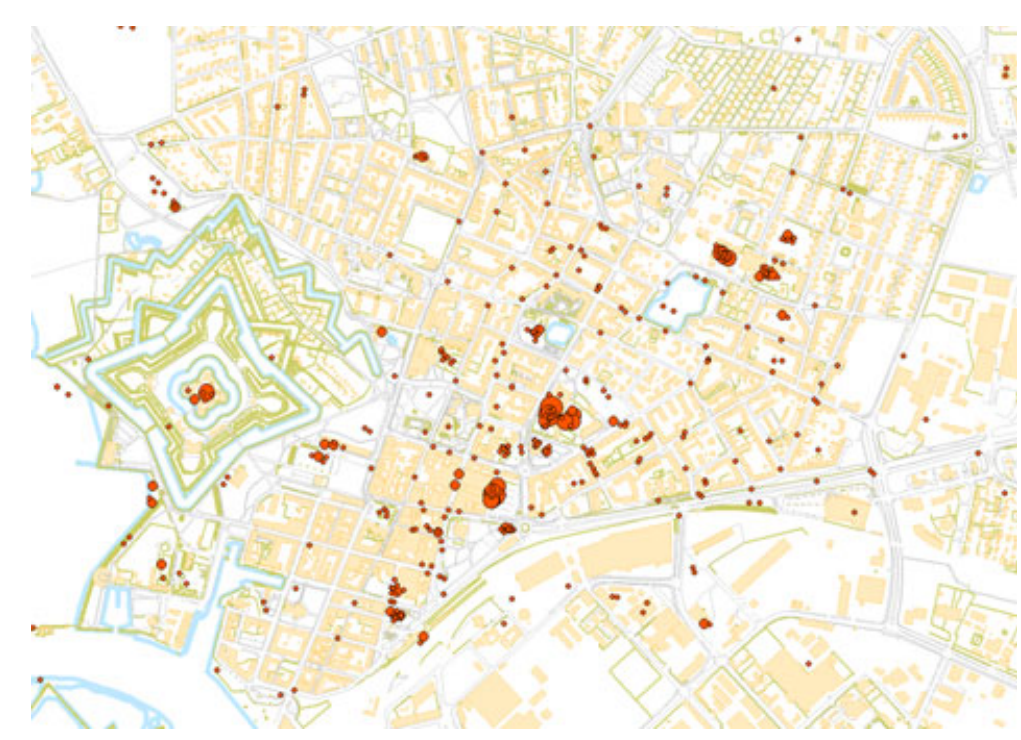

Figure 1: Places Marked as Disliked and Avoided (The Bigger the Circles, the More Marking).

as a meeting place: 'Where is McDonald's? It's cool to be there, and it feels like fun, and to meet friends' (Girl).

The collective sense-making is also evident in relation to places that are marked and talked about as disliked and avoided, especially places in one neighbourhood that is situated in the east of the town centre (Figure 1). Two places in particular are singled out. One of them is a street that the children use because several of their favourite places are located there: sweet shop, bowling alley and video shop. For children who live in the centre, it is also one of several streets that link the eastern parts with the western parts of the town. The other place is an area around one of the participating schools.

For the marked street, the lowest of the bigger circles, the children make a clear distinction between indoors and outdoors by marking their favourite shops as favourite places and the street outside as a disliked place. One reason why the street is disliked is that people "hang around' there. They find this frightening. In the descriptions of the place they also tell of things that happen there. One boy relates:

Boy: I would put a marker there [the street].

Interv: What happens in that street?

Boy: There are people, and I don't want to be mean now, but mostly from [other countries]. There are many people like that in the town. Most of the teenagers carry on and do strange things. Once they set off some dynamite. So one time there outside [the video shop] I thought there would be a fight, because there was a mother and two children sitting in the car and there was a whole gang of that kind, and perhaps one odd Swede, and I think they did something to the car, maybe just kicked it. So they said, "Do you think it's okay to do that?" and they said, "Uhh, what do you want?" or something like that. Then I got a bit, you know. 
The boy's understanding of the place is built on personal experience, but also on dominant images about it. He has witnessed events that confirm the reputation of the street for trouble, but he also talks about things he has heard tell of, for example, about dynamite explosions. In the conversation he, like several other children, links his perception of the street to an existing problem-based image of it. Linked to this image is the perception of the category immigrants to which he is referring, using the expression 'that kind'.

The same kind of associations is made with the other most marked place, which is the area around one of the participating schools (the highest of the bigger circles). The markings are partly linked to the physical environment. Children who move about the area around the school find it badly lit and hence dark. However, just as with the street mentioned above, the markers are strongly connected to people who live or hang around in the area. In the collective narrative about it, the neighbourhood is described as dilapidated and dangerous. For example, it is singled out in the police's citizen survey (2010) as perceived as being the least safe place in the town, due to the fear of being attacked or robbed. This fear also exists in the participating children. Their markers proceed from beliefs that things happen there. Few children, however, have actually experienced any of the things they think might happen. When asked whether anything has happened to them, most of them reply like the children below:

Girl: There are lots of creepy people sitting on benches, you know, ... they might come up to you, like.

Interv: Do they ever say anything special or take things or hit you?

Girl: No, but they always come, like. When you walk past them they stand laughing and that. Just as if they were going to follow you.

Well, when you walk past you can hear them talking dirty ... and ... sometimes you see girls who just stare when you walk past (Boy)

As illustrated by the quotations, the children convey a feeling that 'something' will happen when they pass, not that anything actually has happened. Often the feeling is based on what they have heard, as with this girl: 'I've heard a bit about it, about what it's like. People who tell stories'. What they have heard coincides in large measure with the dominant narrative about the neighbourhood namely, that it is dangerous and rowdy.

It is evident that the children's knowledge about the two most marked places is formed both by experience through mobility in and around them, and by existing spatial knowledge in form of place-images. However, although children in all the schools mark the two places, there is a difference in the way they mark and talk about them. This applies especially to the area around the school. The children from the three other schools mostly speak of the school and the neighbourhood as a unit. When they talk about the two marked places, they frequently refer to the idea prevailing in the town about the entire neighbourhood as troublesome. The children who attend the school are more nuanced. They mark specific places around the school, and in the neighbourhood. They also talk in more positive terms about both the school and the actual neighbourhood. As for children in other studies (Reay, 2007; Van der Burght, 2006), their emplaced knowledge of the area partly contradicts the collective image of it. 


\section{Place-image and the school in the neighbourhood}

The images that exist about the neighbourhood where the two most frequently marked places are located also concern the pupils who attend the school in the area. Children at the other three schools often talk about the pupils in negative terms:

I don't like the whole of the [X] area. There's a lot of bullying there, and I really think that school is unpleasant because every time you have to do something there, some youths always come up to you. Boy

Where is [X] school? They are creepy. They're all so terribly cocky. Girl They don't behave, they think they're so cool. Girl

The children express relatively fixed ideas about what the pupils at the school are like and about what they 'do'. As the quotations show, their characteristics and actions are described in terms of bullying, not behaving, being cocky and quarrelsome. Often links are made to the category of 'immigrants'. If you get into trouble with a person who is defined as belonging to the category, he or she is assumed to come from this school. A boy from the school on the outskirts of the town tells of a person with whom they often get into a row: 'One that we always quarrel with, he's got some funny name, I would guess that he goes to [X] school'. The pupils at the school, like their neighbourhood, represent what is threatening - danger and trouble - and bad behaviour.

It is clear that the children at the other three schools position themselves against the children at the school in the marked neighbourhood. What 'they' are like is a negative contrast to what 'we' are like. This is seen most clearly among children at the school on the outskirts of the town. As we have seen, this school is in an area mainly inhabited by middle- and highincome people and people with a 'Swedish' background. In the positioning they take on the narrative prevalent in the town concerning the relationship between the categories 'Swedes' and 'immigrants'. One such narrative, linked to the marked neighbourhood and its inhabitants, is based on an image that there are dangerous 'gangs':

Boy 1: There are quite a few gangs with loads of immigrants.

Girl 2: It's only immigrant. And they carry on ... Against people who haven't done anything.

Interv: Have you been affected personally?

Both: No.

Interv: And any of you?

Girl 1: No, but I have seen them.

Boy 2: Yeah, you see them. Passing glimpses and the like.

The image of 'gangs' is a commonly used symbol in the town for the neighbourhood and its inhabitants. It is an image that is mediated by various channels such as adults and media. As the quotation illustrates, the participating children from the school on the outskirts of town are highly engaged in the production and reproduction of this image, an image that affects their understanding of and relations to the children in the school in the area. The same kind of production and reproduction is done by the children in the two other schools. This is despite the fact that some of them live in the marked neighbourhood or have siblings and friends who attend the school there. 
Halldén (2007) claims that children create their social position in relation to places. Descriptions of places become a way to emphasise one's own position. Places, according to her, are thus a metaphor for a position in society. The markings and descriptions that the children at the three schools make in relation to the fourth school can be interpreted as an attempt to assert a social position. In this positioning they use existing place-images that are linked to socioeconomic position and to the category of 'immigrants'. The positioning is also done by children who live in the area themselves, or who could be identified by others as belonging to the category. The point is thus that the place knowledge is used for differentiation, despite background. The spatial knowledge used is, however, not only local but also intertwined with global and national narratives. As Holloway and Valentine (2000b) stress, with reference to Massey (1998), local cultures need to be thought of as interactions with global influences. From this point of view, children's local worlds of meaning are also shaped by interconnections with the wider world. This also applies to place-images linked to neighbourhoods and its inhabitants. Waquant (2007) argue that in cities there are stigmatised areas which tend to be exposed to discourses of vilification, both 'from below', in the ordinary actions of daily life, and 'from above', in the journalistic, political and bureaucratic field. The positioning and the creation of 'we' and 'the others' that the pupils at the three schools do in relation to the fourth school could thus, following Waquant, be regarded as not just being rooted in a local context but also part of a larger context.

\section{Place-image and emplaced knowledge}

The reputation of the marked neighbourhood and its school is not unknown to the children who attend the school. During the interviews they make statements like: "they say that our school sucks and things like that' and 'lots of people hate our school'. On one occasion, when a group of pupils were talking about another school, a girl said: 'the pupils there say that our school is the worst'. The children themselves express mixed opinions about their neighbourhood and their school. To some extent their own experiences coincide with the dominant narratives about the neighbourhood as troublesome. A boy and a girl explain why they don't like the area around the school:

Girl: They fight there, sometimes.

Boy: Yes, they threaten me! Every time I pass by, they say, you can't fight, come on, you are cowards. You can't fight!

In the afternoons the area around the school is populated with older children hanging around. These are the ones the boy and girl are referring to. Even though the children's emplaced knowledge to some extent tends to coincide with the reputation of the neighbourhood, it is not always the case. Other studies show that negative images about places also are contradicted by children's emplaced knowledge of these places (Bunar, 2010; Chawla and Malone, 2003; Christensen, 2003; Gustafson, 2006; Reay, 2007; Van der Burght, 2006). This is also true in relation to the children in the identified school who also like their neighbourhood:

Girl 1: Viktoria Street, I enjoy very much.

Interv: It is here.

Girl 1: I like my room a lot and I like my yard too.

Interv: What is good about your yard?

Girl 1: Eh, it's so big, and ... 
Boy: I like the street where I live.

Girl 1: I like [the area around the school].

Girl 2: Me too.

As Christensen (2003) points out, children are faced with the task of integrating spatial knowledge with their developing emplaced knowledge of neighbourhoods. For the children above these are different types of knowledge that do not always match. Like the workingclass children in Reay's (2007) study, the children in this study therefore are confronted with ambivalence and equivocation in relation to where they live and who they are expected to be. This is also something they have to confront and deal with.

\section{Conclusion}

The aim of this article has been to investigate how children use different types of knowledge of place to make sense of their relations to other children. A significant outcome is that participating children connect emplaced and spatial knowledge in their efforts to understand themselves and others. Their emplaced experiences - such as quarrels, being molested and a feeling of insecurity - form their knowledge of the two most disliked and avoided places on the map. Their understanding of the entire neighbourhood where these places are situated and its inhabitants is, however, also influenced by existing place-images. This spatial knowledge affects the children's interpretation of events they see and are involved in when moving around in the neighbourhood. The children's emplaced knowledge is thus not separated from the local spatial knowledge of the area. Instead these two forms of knowledge of place are intertwined and together shape the children's understanding of themselves and others. However, the participating children's emplaced knowledge sometimes contradicts existing place-images. This concerns to a high extent the children in the marked neighbourhood. It is clear that the spatial knowledge in terms of place-images about their own neighbourhood as troublesome and dangerous does not always agree with their emplaced knowledge.

Another significant result of the study is that the participating children are engaged in an exchange of knowledge of place with other children and with adults. This interactivity can be captured with Corsaro's (2005) concept of interpretative reproduction. The term interpretative captures children's participation in their own unique peer cultures by taking information from the adult world, while the term reproduction captures the idea that children not only internalise society and culture, but actively contribute to cultural production and change. In this study it is clear that the children among themselves use societal narratives about the category of 'immigrants' and 'their' residential area to make a distinction between 'us' and 'them'. In doing so they produce and reproduce the patterns that exist between adults in the town (Harju, 2011). The participating children thus both affect and are affected by the society they are a part of, which is a result in line with discussions about children and childhood within childhood sociology (Corsaro, 2005; James and Prout, 1990; Qvortrup, 1994).

The exchange of knowledge of place does not only take place between children and children and adults at the local level. Children's and adults' understanding of locality is intertwined with global and national discourses about places and social categories. The narratives used by participating children to create a sense of 'us' and 'them' are thus interconnected with the wider world. The interactions between the local and global influences have not been the focus of this study, but other studies show that global discourses affect 
children's sense-making of place. In the study by Holloway and Valentine (2000b), for example, it was clear that children in New Zealand and England imagined each other through a complex mix of stereotypical understanding of difference as well as assumptions of sameness. The authors argue that, by employing a more progressive sense of place, in which the local and global are understood as embedded within one another, it is possible to produce more fully contextualised studies of childhood. A future study where children's understanding of themselves and others is related to local and global influences of locality would therefore be an important contribution to the understanding of children's lives and childhoods.

\section{Acknowledgement}

I am grateful to the Skåne Regional Council, the self-governing authority of Skåne, Sweden, for the financial support of the project on which this article is based. I would also like to thank Bodil Rasmusson at the School of Social Work, Lund University for valuable comments on the text.

\section{Notes}

1 In the collective narrative in the town the category of 'immigrant' is mainly connected with people who have immigrated to Sweden since the end of 1980s (Harju, 2011).

2 Place of birth is used here as a definition of the concept.

\section{References}

Berglund U, Nordin K. 2005. Using GIS to make young people's voices heard in urban planning. Built Environment 33: 469-481. No. 4.

Bunar N. 2010. The geographies of education and relationships in a multicultural city. Acta Sociologica 53: 141. DOI: $10.1177 / 0001699310365732$.

Castonguay G, Jutras S. 2009. Children's appreciation of outdoor places in a poor neighbourhood. Journal of Environmental Psychology 29: 101-109. D0I: 10.1016/j.jenvp.2008.05.002.

Chawla L, Malone K. 2003. Neighbourhood quality in children's eyes. In Children in the City: Home, Neighbourhood and Community. Christensen P, 0'Brien M (eds.). Routledge: New York; 118-141.

Christensen P. 2003. Place, space and knowledge: Children in the village and the city. In Children in the City: Home, Neighbourhood and Community. Christensen P, O'Brien M (eds.). Routledge: New York; 13-29.

Christensen P, 0'Brien M (eds.). 2003. Children in the City. Home, Neighbourhood and Community. Routledge: New York.

Corsaro WA. 2005. The Sociology of Childhood. Sage Publications: Thousand Oaks.

Elsley S. 2004. Children's experience of public space. Children \& Society 18: 155-164. D0I: 10.1002/ CHI.822.

Gustafson K, 2006. Vi och dom i skola och stadsdel: Barns identitetsarbete och sociala geografier. [Us and them in school and neighbourhood: Children's identity work and social geographies]. Uppsala Studies in Education no. 111. Pedagogiska institutionen: Uppsala universitet: Uppsala.

Halldén G. 2007. Den moderna barndomen och barns vardagsliv [The Modern Childhood and Children's Everyday Life]. Carlssons Bokförlag: Stockholm.

Harju A. 2011. "Vi" och "Dom" - kollektiva föreställningar i staden ["Us" and "Them" - collective images in the city]. In Hela staden. Social hållbarhet och deintegration? Salonen T (ed.). Borea Bokförlag: Umeå; 177-190.

Holloway SL, Valentine G. 2000a. Spatiality and the new social studies of childhood. Sociology 34: 763. DOI: $10.1177 /$ S0038038500000468. 
Holloway SL, Valentine G. 2000b. Corked Hats and Coronation Street: British and New Zealand children's imaginative geographies of the other. Childhood 7: 335. DOI: 10.1177/0907568200007003006.

James A, Prout A. 1990. Constructing and Reconstructing Childhood: Contemporary Issues in the Sociological Study of Childhood. The Falmer Press: London.

Johansson J. (2011). "Det var bättre förr": Samhällsförändring och nostalgi ["It was better in the past: societal change and nostalgia]. In Hela staden. Social hållbarhet och deintegration? Salonen T (ed.). Borea Bokförlag: Umeå; 33-54.

Lieberg M. 1992. Att ta staden $i$ besittning: Om ungas rum och rörelse $i$ offentlig miljö. Lunds universitet: Byggnadsfunktionslära.

Massey D. 1998. The spatial construction of youth cultures. In Cool Places: Geographies of Youth Cultures. Skelton T, Valentine G (eds.). Routledge: London; 122-130.

Matthews H. 2003. The street as a liminal space: the barbed spaces of childhood. In Children in the City: Home, Neighbourhood and Community. Christensen P, O'Brien M (eds.). Routledge: New York; 101-117.

McKendrick JH. 2000. The geography of children: an annotated bibliography. Childhood 7: 359. DOI: $10.1177 / 0907568200007003007$.

0'Brien M. 2003. Regenerating children's neighbourhoods: what do children want?. In Children in the City: Home, Neighbourhood and Community. Christensen P, O’Brien M (eds.). Routledge: New York; 142-161.

Philo C. 2000. The corner-stones of my world: editorial introduction to special issue on spaces of childhood. Childhood 7: 243. DOI: 10.1177/0907568200007003001.

Qvortrup J. 1994. Childhood matters: an introduction. In Childhood Matters: Social Theory, Practice and Politics. Qvortrup J, Bardy M, Sgritti G, Winterberger H (eds.). Avebury: Aldershot; 1-23.

Rasmusson B. 1998. Stadsbarndom: Om barns vardag $i$ en modern förort [Urban Childhood: Everyday Life of Children in a Modern Suburb]. Lunds universitet: Meddelande från Socialhögskolan.

Reay D. 2007. 'Unruly Places': inner-city comprehensives, middle-class imaginaries and working-class children. Urban Studies 44: 1191-1201. No. 7. DOI: 10.1080/00420980701302965.

Salonen T (ed.). 2011. Hela staden: Social hållbarhet och desintegration? [The Whole City: Social Sustainability and Disintegration?]. Borea Bokförlag: Umeå.

Scarpa S. 2011. 'Statlig påverkan på den lokala arenan' [State influence on the local arena]. In Hela staden. Social hållbarhet och desintegration? Salonen T (ed.). Borea Bokförlag: Umeå; 55-73.

Shields R. 1991. Places on the Margin. Alternative Geographies of Modernity. Routledge: London.

Travlou P, Eubanks Owens P, Ward Thompson C, Maxwell K. 2008. Place mapping with teenagers: locating their territories and documenting their experience of the public realm. Children's Geographies 6: 309-326. No. 3. DOI: 10.1080/14733280802184039.

Van der Burght D. 2006. "Där man bor tycker man att det är bra". Barns geografier $i$ segregerade stadsmiljöer. ["Where you live you like it”. Children's Geographies in a Segregated Urban Environment]. Uppsala universitet: Geografiska regionsstudier.

Waquant L. 2007. Territorial stigmatization in the age of advanced marginality. Thesis Eleven, November 2007: 66-77. No. 91. DOI: 10.1177/0725513607082003.

Correspondence to: Anne Harju, Senior Lecturer, Department of Children, Youth and Society, Faculty of Education, Malmö University, 20506 Malmö, Sweden. E-mail: anne.harju@mah.se

\section{Databases}

Polismyndighetens medborgarundersökning. [Police’s citizen survey].

http://www.landskrona.se/bra. (accessed 18 November 2010). 